$\underline{\xi}=-m$

\title{
Evaluation of metals content among different cosmetic products in the Arabian market
}

\author{
Sahar Younes Ibrahim Md ${ }^{1 *}$, Rania Abdel Maguid Md ${ }^{1}$, Maha Khaled Al-Mazroua ${ }^{2}$ \\ ${ }^{1}$ Department of Forensic Medicine and clinical Toxicology. Faculty of Medicine - Alexandria University \\ ${ }^{2}$ Director of Dammam Regional Poison Control Center - Eastern Region, Kingdom of Saudi Arabia \\ *Corresponding author E-mail: sahar_issa71@yahoo.com
}

\begin{abstract}
Background: Cosmetics' use is very popular all over the world and in some parts of Arabian countries. The use of some cosmetics as Kohl is part of culture and traditions, and is used since very young ages. This makes detection of heavy metal content in cosmetics marketed in Egypt and other Arabian markets of crucial importance.

Objective: To evaluate the levels of heavy metals content among different cosmetic products in the Arabian market.

Methods: Different brands of; anti-freckle creams, eye shadows, eyeliners, facial powders, foundation, henna and lipsticks were purchased from open markets in Egypt and Saudi Arabia. Sample preparation and analysis was conducted, to estimate levels of twelve different metals ( $\mathrm{Pb}, \mathrm{As}, \mathrm{Cd}, \mathrm{Ag}, \mathrm{Ba}, \mathrm{Al}, \mathrm{Cr}, \mathrm{Mn}, \mathrm{Co}, \mathrm{Ni}, \mathrm{Cu}$, and $\mathrm{Zn}$ ) using Inductively Coupled Plasma Mass Spectrometry (ICP-MS).

Results: The mean concentration of some studied metals as Aluminium, lead, arsenic, copper and nickel were higher than permissible levels for cosmetics in some of the studied samples. Para- Phenylenediamine (PPD) was detected in all the studied 7 Henna samples.

Conclusion: In conclusion, cosmetic contamination with metals above permissible levels is very common in most of the products available in the developing world and Arabian markets. Physicians and users must be aware of the probable toxicity of these elements and of the clinical signs of systemic poisoning. Considering popular use of cosmetics by different age groups, the hazardous cumulative effects of prolonged exposure to low concentrations of metals like; Aluminium, lead, Arsenic, nickel and copper especially in children, cannot be ruled out. Further studies are recommended in addition, cosmetic market control and legislation procedures should be thoroughly implemented.
\end{abstract}

Keywords: Cosmetics; Henna; Lipstick; Heavy Metals; Aluminum; Lead; ICP-MS; Traditional Herbs; Allergic Dermatitis; Poisoning; Toxicity; Arabian Market.

\section{Introduction}

The definition of a cosmetic identifies the site of application (epidermis, hair system, nails, lips, eyes) and the intended functions (cleaning, perfuming, changing the appearance, correcting body odours, protecting and, keeping in good condition). (Amparo Salvador and, Alberto Chisvert, 2007) During the past decades the safety of cosmetic products and their ingredients has attracted greater than ever attention; thus their toxicological safety evaluation is a relatively young discipline, which evolved in the second half of the $20^{\text {th }}$ century. Up to the 1960 s it was commonly believed that cosmetic products will never go beyond the surface of the human body. Therefore, local effects were the primary safety concern. The first consistent in vivo tests for skin and eye irritation were developed in the 1940s. (Draize 1944) Oral exposure can occur from wearing of cosmetic products containing heavy metal impurities around the mouth and also from hand to mouth contact. (Sainio et al., 2002).

Cosmetic formulations are that class of products whose atypical features can be well thought-out, from a biochemical and toxicological point of view, as intermediary between both foods and drugs. For undeniably, the frequency of use of cosmetic formulations is generally scheduled on a daily basis, and in some instances several cosmetic products, like, for example, a lipstick or a hand cream, can be applied to the body twice or more times a day. Sim- ultaneously, the techniques that are generally used in the production of a great variety of cosmetic formulations are directly derived from the experience of pharmaceutics. (Marcelo E. et al. 1996).

Some heavy metals have been used as cosmetics ingredients previously. Examples include the preservative thimerosal (mercury), the hair dye lead acetate and a number of tattoo pigments such as red cinnabar (mercuric sulphide). As the issue of heavy metals as intentional cosmetics ingredients has been thoroughly studied, awareness turns nowadays to the presence of these substances as impurities. (Omolaoye J.A. 2010) It is therefore evident that any action devoted to the definition of the possible risks for the consumer due to the presence of toxic substances in a cosmetic formulation is to be robustly supported. That's why; many countries legalize the procedures to be followed for the commercialization of cosmetic products. (Marcelo E. et al. 1996).

Henna (Lawsonia inermis) had been used as a hair colorant and decorative medium for long time. (Kumar S. et al. 2005 and Roy PK. et al. 2005) The hair coloring agents market is dominated by cosmetic companies mostly marketing chemical based colors. (Bolduc C., Shapiro J. 2001) It is an accepted fact that all chemicals have some side effects, convincing more discerning customers to use herbal based substitutes; that's why it was accepted that scientists and cosmetologist made use of henna as a chemical substitute for making hair colors. (Charles Z. 1986). 
When henna paste is applied to the skin the dye (lawsone) migrates from the paste to the outermost layer of the skin, thus creating a red-brown stain. Additionally, henna plant extract and essential oils can be used either in its concentrated or diluted forms and mixed with another materials in industrial products (Roy P K, et al. 2005).

Besides its use in cosmetics, the henna leaves are used as a prophylaxis against skin diseases (Ahmed at al., 2000), as well as in treating diarrhoea, renal lithiasis (Bellakhdar, 1997) and, abdominal pain (Lahsissene and Kahouadji, 2010).

Para- Phenylenediamine (PPD), a derivative of Para-nitro aniline is widely used in hair dye formulations, to deepen the color of henna and to accelerate the coloring process. Local application of PPD in vulnerable individuals may result in dermatitis, asthma, arthritis, lacrimation, exophthalmos or even permanent blindness when applied to the eyes. Oral ingestion of PPD might be fatal and results in renal failure, severe edema of face, tongue, neck and laryngeal edema with respiratory distress often requiring emergency tracheostomy. (Yagi H. et al. 1994).

\section{Methods}

\subsection{Heavy metals}

Accurately weighed portion $(0.1-0.2 \mathrm{~g})$ of each cosmetic sample was transferred to a TEFLON digestion tube $(120 \mathrm{~mL})$ and $7.0 \mathrm{~mL}$ of the acid mixture Nitric/ Hydrofluoric/hydrochloric acids $\left(\mathrm{HNO}_{3} / \mathrm{HF} / \mathrm{HCl}, 4.5: 2: 0.5\right)$ was introduced. The tube was sealed and the sample was digested inside a microwave oven (Milestone ETHOS 1600). After being cooled to ambient temperature, the tube was opened; the inside of the lid was rinsed with distilled and de-ionized water (DDW) and the mixture heated on a hotplate $\left(120{ }^{\circ} \mathrm{C}\right)$ for 30 minutes to drive off the residual $\mathrm{HF}$ and $\mathrm{HCl}$. The resulting digest was filtered in a polypropylene flask using $1 \%$ $\mathrm{HNO}_{3}$ and made up to $50 \mathrm{ml}$ volume. For ICPMS measurement the clear digest obtained were diluted 10 times using DDW. Samples and standard reference materials (SRM) were prepared in a batch of six including a blank $\left(\mathrm{HNO}_{3} / \mathrm{HF} / \mathrm{HCl}\right)$ digest. (Bolann $\mathrm{BJ}$, et al 2007) Twelve different metals ( $\mathrm{Pb}, \mathrm{As}, \mathrm{Cd}, \mathrm{Ag}, \mathrm{Ba}, \mathrm{Al}, \mathrm{Cr}, \mathrm{Mn}$, $\mathrm{Co}, \mathrm{Ni}, \mathrm{Cu}$, and $\mathrm{Zn}$ ) in all prepared solutions were quantified subsequently by ICP-MS.

\subsection{Organic substances}

Selected henna products were analysed quantitatively for the content of PPD. The analysis for PPD was performed by Gas chromatography/mass spectroscopy (GC/MS) (GC $6890 \mathrm{~N}$, MS $5973 \mathrm{~N}$ ) analyses was performed using a GC-MS system G1800 Series II (Agilent Technologies Inc., Palo Alto, CA, USA), equipped with an HP-5MS $(30 \mathrm{~m} \times 0.25 \mathrm{~mm}$, Ph Mesiloxane $5 \%)$ capillary column. (Hatem Abdel Moniem Ahmed, et al. 2013).
High purity water (DDW) (Specific resistivity $18 \mathrm{M} \Omega . \mathrm{cm}^{-1}$ ) obtained from a Milli Q - pure water purification system (Millipore SAS, France) was used throughout the work. All solvents, chemicals and, reagents used were purchased from MERCK, (Darmstadt, Germany). PPD internal standard (IS) was prepared by weighing pure PPD substance (Sigma Life Science, 0.011 gram) and dissolving it in $50 \%$ aqueous methanol solution $(100 \mathrm{~mL})$.

One gram of each of the collected samples was weighed into a 50 $\mathrm{mL}$ volumetric flask and diluted with $50 \%$ aqueous methanol solution $(50 \mathrm{~mL})$. This solution was then filtered after 15 minutes. Finally one $\mathrm{mL}$ of this solution was diluted to $5 \mathrm{~mL}$ with $50 \%$ aqueous methanol solution and analysed for PPD. (Hatem Abdel Moniem Ahmed, et al. 2013).

\subsection{Samples}

Different brands of; anti-freckle creams, eye shadows, eyeliners, facial powders, foundation, lipsticks and henna were purchased from local markets in Egypt, and Saudi Arabia. All the samples were purchased by different commercial suppliers located in the local markets of both countries. The brand names were blinded and given the codes 1 to 25 . The other details are presented in table (1).

\subsection{Statistical analysis}

Data for metal estimation have been tabulated and the results were analyzed statistically and expressed as mean \pm SD. The concentrations of metals were presented in table (2), and were expressed as mean \pm SD. The percentage concentration of PPD in all studied Henna samples was tabulated in table (3).

\section{Results}

\subsection{Laboratory studies}

In this study, we have tested twenty five cosmetic products for the presence of twelve different metals ( $\mathrm{Pb}, \mathrm{As}, \mathrm{Cd}, \mathrm{Ag}, \mathrm{Ba}, \mathrm{Al}, \mathrm{Cr}$, $\mathrm{Mn}, \mathrm{Co}, \mathrm{Ni}, \mathrm{Cu}$, and $\mathrm{Zn}$ ) using ICP-MS. The distribution of heavy metals in samples studied is shown in table (2) expressed as mean \pm SD. Metals were detected in most of the samples in varying concentrations. However, clear patterns indicating that metal concentrations were related to specific brands, cost, or colour were not detected. The result of this experiment revealed that the distribution frequency of metals among the studied samples were; $\mathrm{Pb}$, $\mathrm{As}, \mathrm{Cd}, \mathrm{Ag}>\mathrm{Zn}, \mathrm{Mg}>\mathrm{Al}>\mathrm{Ba}, \mathrm{Ni}>\mathrm{Co}$. The distribution frequency of Cobalt was the least among the studied elements (detected in 10 samples only). Aluminium was detected in most of the studied samples (22 samples). The seven Henna samples were tested for the presence of PPD using GC-MS, and the concentrations of PPD were presented in table (3).

\subsection{Chemicals}

Table 1: Details of Purchased Cosmetic Products

\begin{tabular}{lll}
\hline Sample Code & Type & Uses as written on the product \\
\hline $1-3$ & Anti-freckle creams & Depigmentation, skin cleansing and fairness. \\
$4-6$ & Eye shadows & Cosmetic colouring of eye lids. \\
$7-9$ & Eye liners & Eye Demarcation. \\
$10-12$ & Facial powders & Improve the complexion. \\
$13-15$ & Foundations & Anti-aging, tone up the skin, tighten the pores. \\
$16-18$ & Lip sticks & Lip colour, and moisturizer. \\
$19-25$ & Henna powder & Skin pigmentation and Tattooing. \\
\hline
\end{tabular}


Table 2: Concentrations of Metals in Cosmetic Product

\begin{tabular}{|c|c|c|c|c|c|c|c|c|c|c|c|c|}
\hline \multirow{2}{*}{$\begin{array}{l}\text { Sam- } \\
\text { ple } \\
\text { Num- } \\
\text { ber }\end{array}$} & \multicolumn{12}{|c|}{ Metals studied (Mean \pm SD) } \\
\hline & $\mathrm{Pb}$ & As & $\mathrm{Cd}$ & $\mathrm{Ag}$ & $\mathrm{Ba}$ & $\mathrm{Al}$ & $\mathrm{Cr}$ & $\mathrm{Mg}$ & Co & $\mathrm{Ni}$ & $\mathrm{Cu}$ & $\mathrm{Zn}$ \\
\hline 1 & $\begin{array}{l}33.100 \pm 1.97 \\
5\end{array}$ & $\begin{array}{l}1.563 \pm 0.03 \\
8\end{array}$ & $\begin{array}{l}0.625 \pm 0.00 \\
0\end{array}$ & $\begin{array}{l}0.076 \pm 0.01 \\
0\end{array}$ & ND & $230 \pm 21.63$ & $\begin{array}{l}27.07 \pm \\
6.15\end{array}$ & $112 \pm 0$ & $\begin{array}{l}2.06 \\
\pm \\
0.19\end{array}$ & $\begin{array}{l}2.14 \\
\pm \\
0.18\end{array}$ & $20.5 \pm 0.7$ & $6.6 \pm 0.00$ \\
\hline 2 & $\begin{array}{l}20.580 \pm 3.74 \\
6\end{array}$ & $\begin{array}{l}1.430 \pm 0.03 \\
5\end{array}$ & $\begin{array}{l}0.658 \pm 0.05 \\
8\end{array}$ & $\begin{array}{l}0.083 \pm 0.01 \\
0\end{array}$ & $\begin{array}{l}38.58 \\
\pm \\
3.26\end{array}$ & $275 \pm 55.75$ & $\begin{array}{l}7.3 \pm \\
4.97\end{array}$ & $3508 \pm 115$ & $\begin{array}{l}1.06 \\
\pm \\
0.12\end{array}$ & $\begin{array}{l}3.74 \\
\pm \\
0.68\end{array}$ & $21.9 \pm 0.3$ & $4.8 \pm 0.15$ \\
\hline 3 & $\begin{array}{l}16.630 \pm 3.99 \\
2\end{array}$ & $\begin{array}{l}1.887 \pm 0.02 \\
1\end{array}$ & $\begin{array}{l}0.625 \pm 0.00 \\
0\end{array}$ & $\begin{array}{l}0.278 \pm 0.01 \\
1\end{array}$ & ND & $325 \pm 69.50$ & $\begin{array}{l}5.60 \pm \\
4.12\end{array}$ & $1358 \pm 14$ & ND & $\begin{array}{l}23.1 \\
\pm \\
0.25\end{array}$ & $22.2 \pm 0.5$ & $6.89 \pm 0.09$ \\
\hline 4 & $6.750 \pm 2.479$ & $\begin{array}{l}3.423 \pm 0.04 \\
5\end{array}$ & $\begin{array}{l}0.992 \pm 0.32 \\
1\end{array}$ & $\begin{array}{l}2.183 \pm 0.02 \\
6\end{array}$ & $\begin{array}{l}66.15 \\
\pm \\
3.06\end{array}$ & $\begin{array}{l}3780 \pm 95.0 \\
9\end{array}$ & $\begin{array}{l}12.0 \pm \\
3.50\end{array}$ & $2071 \pm 566$ & ND & $\begin{array}{l}9.65 \\
\pm \\
1.53\end{array}$ & $24.3 \pm 0.5$ & $\begin{array}{l}21.11 \pm 0.2 \\
4\end{array}$ \\
\hline 5 & $\begin{array}{l}12.030 \pm 3.99 \\
5\end{array}$ & $\begin{array}{l}2.923 \pm 0.04 \\
5\end{array}$ & $\begin{array}{l}0.692 \pm 0.11 \\
5\end{array}$ & $\begin{array}{l}0.157 \pm 0.02 \\
1\end{array}$ & $\begin{array}{l}21.30 \\
\pm \\
4.02\end{array}$ & $806 \pm 90.27$ & $\begin{array}{l}1.40 \pm \\
2.20\end{array}$ & $475 \pm 38$ & ND & ND & $19.5 \pm 0.1$ & $31.4 \pm 0.34$ \\
\hline 6 & $9.390 \pm 3.438$ & $\begin{array}{l}3.683 \pm 0.18 \\
1\end{array}$ & $\begin{array}{l}1.158 \pm 0.20 \\
8\end{array}$ & $\begin{array}{l}0.309 \pm 0.02 \\
1\end{array}$ & $\begin{array}{l}54.15 \\
\pm \\
3.10\end{array}$ & $\begin{array}{l}1122 \pm 87.4 \\
0\end{array}$ & $\begin{array}{l}3.74 \pm \\
1.70\end{array}$ & $8317 \pm 83$ & $\begin{array}{l}3.34 \\
\pm 0.6 \\
1\end{array}$ & $\begin{array}{l}3.41 \\
\pm \\
0.74\end{array}$ & $22.0 \pm 0.6$ & $\begin{array}{l}18.69 \pm 0.4 \\
0\end{array}$ \\
\hline 7 & $\begin{array}{l}11.350 \pm 2.96 \\
3\end{array}$ & $\begin{array}{l}2.237 \pm 0.03 \\
8\end{array}$ & $\begin{array}{l}1.092 \pm 0.25 \\
2\end{array}$ & $\begin{array}{l}0.072 \pm 0.01 \\
4\end{array}$ & ND & $313 \pm 32.01$ & $\begin{array}{l}1.15 \pm \\
0.22\end{array}$ & $5316 \pm 101$ & ND & $\begin{array}{l}8.45 \\
\pm \\
12.3 \\
0\end{array}$ & $19.9 \pm 0.2$ & $\begin{array}{l}49.26 \pm 0.2 \\
6\end{array}$ \\
\hline 8 & $\begin{array}{l}96.430 \pm 1.97 \\
5\end{array}$ & $\begin{array}{l}1.557 \pm 0.04 \\
2\end{array}$ & $\begin{array}{l}1.875 \pm 0.49 \\
9\end{array}$ & $\begin{array}{l}0.065 \pm 0.01 \\
0\end{array}$ & $\begin{array}{l}1.1 \pm \\
0.05\end{array}$ & $582 \pm 12.86$ & $\begin{array}{l}0.69 \pm \\
0.15\end{array}$ & $7917 \pm 196$ & ND & ND & $22.9 \pm 0.2$ & $\begin{array}{l}50.78 \pm 0.4 \\
1\end{array}$ \\
\hline 9 & $\begin{array}{l}21.400 \pm 1.30 \\
2\end{array}$ & $\begin{array}{l}2.927 \pm 0.04 \\
7\end{array}$ & $\begin{array}{l}1.258 \pm 0.55 \\
1\end{array}$ & $\begin{array}{l}1.095 \pm 0.03 \\
1\end{array}$ & ND & $\begin{array}{l}4779 \pm 82.5 \\
6\end{array}$ & $\begin{array}{l}4.70 \pm \\
0.95\end{array}$ & $8350 \pm 307$ & $\begin{array}{l}1.06 \\
\pm \\
0.09\end{array}$ & ND & $23.2 \pm 0.5$ & $\begin{array}{l}56.57 \pm 0.5 \\
7\end{array}$ \\
\hline 10 & $\begin{array}{l}11.300 \pm 1.98 \\
8\end{array}$ & $\begin{array}{l}3.213 \pm 0.04 \\
0\end{array}$ & $\begin{array}{l}0.758 \pm 0.15 \\
3\end{array}$ & $\begin{array}{l}0.311 \pm 0.01 \\
2\end{array}$ & ND & $\begin{array}{l}5311 \pm 66.5 \\
8\end{array}$ & $\begin{array}{l}0.69 \pm 2 . \\
13\end{array}$ & $8112 \pm 481$ & ND & ND & $20.4 \pm 0.1$ & $\begin{array}{l}46.12 \pm 0.2 \\
6\end{array}$ \\
\hline 11 & $6.750 \pm 0.563$ & $\begin{array}{l}2.637 \pm 0.03 \\
8\end{array}$ & $\begin{array}{l}0.725 \pm 0.17 \\
3\end{array}$ & $\begin{array}{l}0.041 \pm 0.00 \\
7\end{array}$ & ND & $\begin{array}{l}4825 \pm 77.0 \\
3\end{array}$ & $\begin{array}{l}24.70 \pm \\
5.20\end{array}$ & $\begin{array}{l}10681 \pm 90 \\
0\end{array}$ & $\begin{array}{l}0.4 \pm \\
0.21\end{array}$ & $\begin{array}{l}3.2 \pm \\
0.34\end{array}$ & $48.5 \pm 0.4$ & $\begin{array}{l}50.49 \pm 0.5 \\
8\end{array}$ \\
\hline 12 & $\begin{array}{l}10.040 \pm 1.15 \\
8\end{array}$ & $\begin{array}{l}3.077 \pm 0.19 \\
1\end{array}$ & $\begin{array}{l}0.792 \pm 0.23 \\
1\end{array}$ & $\begin{array}{l}0.041 \pm 0.00 \\
4\end{array}$ & $\begin{array}{l}32.07 \\
\pm \\
3.51\end{array}$ & $\begin{array}{l}4268 \pm 36.8 \\
3\end{array}$ & $\begin{array}{l}8.72 \pm \\
0.04\end{array}$ & $4929 \pm 97$ & ND & $\begin{array}{l}7.1 \pm \\
0.30\end{array}$ & $49.1 \pm 0.8$ & $\begin{array}{l}54.01 \pm 0.1 \\
4\end{array}$ \\
\hline 13 & $7.400 \pm 1.975$ & $\begin{array}{l}2.927 \pm 0.04 \\
7\end{array}$ & $\begin{array}{l}0.858 \pm 0.34 \\
3\end{array}$ & $\begin{array}{l}0.168 \pm 0.00 \\
7\end{array}$ & $\begin{array}{l}18.1 \pm \\
1.05\end{array}$ & $\begin{array}{l}4917 \pm 109 \\
8\end{array}$ & $\begin{array}{l}4.30 \pm \\
0.12\end{array}$ & $5146 \pm 159$ & $\begin{array}{l}1.30 \\
\pm 0.3\end{array}$ & ND & $10.0 \pm 0.3$ & $\begin{array}{l}50.46 \pm 2.5 \\
1\end{array}$ \\
\hline 14 & $1.470 \pm 0.852$ & $\begin{array}{l}2.263 \pm 0.02 \\
1\end{array}$ & $\begin{array}{l}0.825 \pm 0.10 \\
0\end{array}$ & $\begin{array}{l}0.118 \pm 0.00 \\
4\end{array}$ & ND & $\begin{array}{l}4511 \pm 89.6 \\
1\end{array}$ & $\begin{array}{l}0.44 \pm \\
1.35\end{array}$ & $475 \pm 38$ & ND & $\begin{array}{l}18.1 \\
\pm \\
2.30\end{array}$ & $10.4 \pm 0.3$ & $\begin{array}{l}39.65 \pm 0.3 \\
0\end{array}$ \\
\hline 15 & $\begin{array}{l}12.850 \pm 0.57 \\
7\end{array}$ & $\begin{array}{l}2.013 \pm 0.00 \\
6\end{array}$ & $\begin{array}{l}0.785 \pm 0.11 \\
5\end{array}$ & $\begin{array}{l}0.278 \pm 0.01 \\
1\end{array}$ & $\begin{array}{l}2.07 \pm \\
0.51\end{array}$ & $\begin{array}{l}5505 \pm 31.6 \\
4\end{array}$ & $\begin{array}{l}2.16 \pm 0.3 \\
2\end{array}$ & $5108 \pm 97$ & ND & $\begin{array}{l}1.53 \\
\pm \\
0.15\end{array}$ & $9.4 \pm 0.3$ & $\begin{array}{l}35.66 \pm 6.9 \\
9\end{array}$ \\
\hline 16 & $11.12 \pm 2.64$ & $1.42 \pm 0.031$ & $1.17 \pm 1.20$ & $0.14 \pm 0.032$ & $\begin{array}{l}28.18 \\
\pm \\
3.14\end{array}$ & ND & $\begin{array}{l}25.41 \pm \\
5.20\end{array}$ & $15 \pm 3.24$ & $\begin{array}{l}1.11 \\
\pm 0.5\end{array}$ & ND & $41.1 \pm 0.4$ & $4.1 \pm 0.17$ \\
\hline 17 & $7.214 \pm 1.21$ & $\begin{array}{l}3.021 \pm 0.13 \\
3\end{array}$ & $0.07 \pm 0.65$ & $0.141 \pm 0.09$ & ND & $344 \pm 12.47$ & $\begin{array}{l}9.50 \pm \\
2.43\end{array}$ & ND & ND & $\begin{array}{l}3.22 \\
\pm \\
0.64\end{array}$ & $19.1 \pm 0.5$ & ND \\
\hline 18 & $9.350 \pm 2.963$ & $\begin{array}{l}1.651 \pm 0.03 \\
5\end{array}$ & $1.40 \pm 0.46$ & $\begin{array}{l}0.321 \pm 0.02 \\
4\end{array}$ & ND & $52 \pm 10.16$ & $\begin{array}{l}0.69 \pm \\
0.15\end{array}$ & $19 \pm 4.211$ & ND & ND & $\begin{array}{l}22.1 \pm 0.6 \\
4\end{array}$ & $14.8 \pm 0.11$ \\
\hline 19 & $6.430 \pm 1.975$ & $\begin{array}{l}2.470 \pm 0.12 \\
4\end{array}$ & $0.08 \pm 1.25$ & $\begin{array}{l}0.355 \pm 0.01 \\
8\end{array}$ & $\begin{array}{l}2.18 \pm \\
1.14\end{array}$ & $12 \pm 14.81$ & $\begin{array}{l}12.06 \pm \\
3.50\end{array}$ & ND & $\begin{array}{l}1.04 \\
\pm 0.7\end{array}$ & ND & $4.12 \pm 0.2$ & $24.1 \pm 0.16$ \\
\hline 20 & $8.400 \pm 1.302$ & $\begin{array}{l}1.830 \pm 0.12 \\
0\end{array}$ & $0.09 \pm 1.35$ & $\begin{array}{l}0.214 \pm 0.05 \\
4\end{array}$ & $\begin{array}{l}3.22 \pm \\
1.02\end{array}$ & ND & $\begin{array}{l}26.07 \pm \\
6.15\end{array}$ & $25 \pm 7.29$ & ND & $\begin{array}{l}7.21 \\
\pm \\
0.14\end{array}$ & $16.1 \pm 0.8$ & $3.2 \pm 0.14$ \\
\hline 21 & $\begin{array}{l}11.300 \pm 1.98 \\
8\end{array}$ & ND & $3.50 \pm 0.70$ & $\begin{array}{l}0.147 \pm 0.02 \\
5\end{array}$ & $\begin{array}{l}2.14 \pm \\
0.19\end{array}$ & $82 \pm 12.71$ & $\begin{array}{l}5.60 \pm \\
4.12\end{array}$ & $79 \pm 13.24$ & ND & ND & $39.1 \pm 0.5$ & ND \\
\hline 22 & $8.400 \pm 1.975$ & $\begin{array}{l}3.927 \pm 0.04 \\
7\end{array}$ & $\begin{array}{l}0.958 \pm 0.34 \\
3\end{array}$ & $\begin{array}{l}0.268 \pm 0.00 \\
7\end{array}$ & $\begin{array}{l}17.1 \pm \\
1.05\end{array}$ & $494 \pm 109.8$ & $\begin{array}{l}4.60 \pm \\
0.12\end{array}$ & $524 \pm 159$ & $\begin{array}{l}1.80 \\
\pm 0.3\end{array}$ & $\begin{array}{l}7.11 \\
\pm \\
0.14\end{array}$ & $11.0 \pm 0.3$ & $\begin{array}{l}50.15 \pm 2.5 \\
1\end{array}$ \\
\hline 23 & $1.240 \pm 0.852$ & $\begin{array}{l}2.215 \pm 0.02 \\
1\end{array}$ & $\begin{array}{l}0.425 \pm 0.10 \\
0\end{array}$ & $\begin{array}{l}0.248 \pm 0.00 \\
4\end{array}$ & ND & $421 \pm 89.61$ & $\begin{array}{l}0.31 \pm \\
1.35\end{array}$ & $275 \pm 38$ & ND & $\begin{array}{l}15.7 \\
\pm \\
2.30\end{array}$ & $7.4 \pm 0.3$ & $\begin{array}{l}24.65 \pm 0.3 \\
0\end{array}$ \\
\hline 24 & $\begin{array}{l}14.850 \pm 0.57 \\
7\end{array}$ & $\begin{array}{l}2.013 \pm 0.00 \\
6\end{array}$ & $\begin{array}{l}0.715 \pm 0.11 \\
5\end{array}$ & $\begin{array}{l}0.278 \pm 0.01 \\
1\end{array}$ & $\begin{array}{l}2.07 \pm \\
0.51\end{array}$ & $545 \pm 31.64$ & $\begin{array}{l}2.16 \pm 0.3 \\
2\end{array}$ & $547 \pm 24$ & ND & $\begin{array}{l}1.85 \\
\pm \\
0.15\end{array}$ & $9.1 \pm 0.3$ & $\begin{array}{l}35.25 \pm 6.9 \\
9\end{array}$ \\
\hline 25 & $17.4 \pm 2.64$ & $1.42 \pm 0.031$ & $1.17 \pm 1.20$ & $0.14 \pm 0.032$ & $\begin{array}{l}28.11 \\
\pm \\
3.14 \\
\end{array}$ & ND & $\begin{array}{l}20.41 \pm \\
5.20\end{array}$ & $11 \pm 3.24$ & $\begin{array}{l}1.11 \\
\pm 0.5\end{array}$ & ND & $32.1 \pm 0.4$ & $7.1 \pm 0.17$ \\
\hline
\end{tabular}

- $\quad$ Results are expressed as average \pm SD for three samples (SD: standard deviation).

- $\quad$ All results are in ppm: Part per million, SD: Standard deviation, ND: not detected $(<\mathrm{DL})$. 


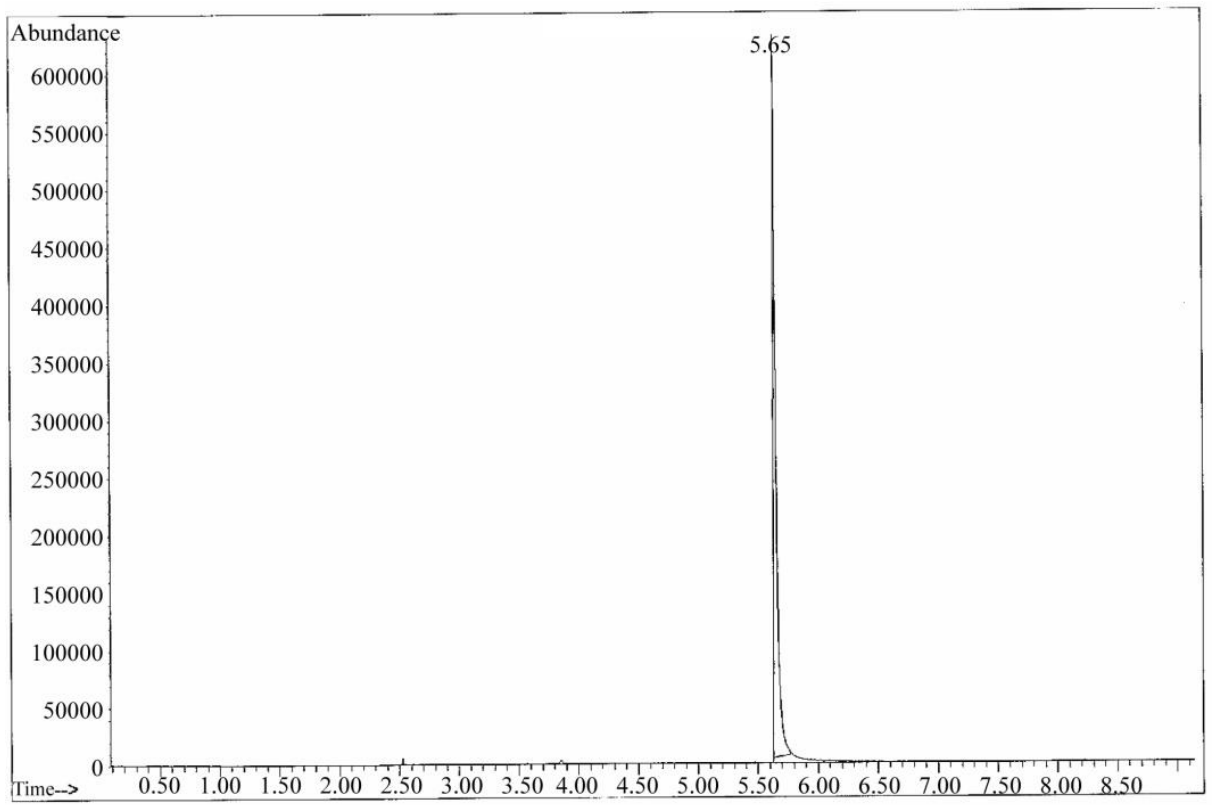

Fig. 1: Retention Time for PPD in One of the Henna Samples Using GC-MS

Table 3: The Concentration of Para-Phenylenediamine in the Studied Henna Samples

\begin{tabular}{ll}
\hline Sample Number & PPD Concentration \\
\hline 19 & 35.210 \\
20 & 17.264 \\
21 & 12.230 \\
22 & 17.215 \\
23 & 14.018 \\
24 & 6.012 \\
25 & 8.521 \\
\hline
\end{tabular}

\section{Discussion}

Back in ancient Egypt, Greece, and Roman Empire times, women had been applying some reddish mineral or plant pigment to their cheeks and lips for the purpose of beautification. Therefore, the history of lip cosmetics might have been over thousands of years. (Brown, 2013)To ensure safety and efficacy, cosmetic products are regulated and controlled worldwide. However, harmonization of laws dealing with cosmetics is far from being achieved and regulatory frameworks vary greatly between countries making it practically impossible for a global industry to sell the same product on all markets. (Amparo Salvador and, Alberto Chisvert, 2007) Cosmetics have often been considered by many dermatologists, more dangerous than good. (Groot et al. 1994) They may contain more than 10,000 ingredients which are related to many diseases like cancer, birth defects, developmental and reproductive harms. Knowing such poisonous effects the (US FDA) Food and Drug Administration in 2011 completely forbidden the presence of nine ingredients including coal tar colors, formaldehyde, glycol ethers, lead, mercury, Phenylenediamine, phthalates in cosmetic products. The density of heavy metals is five folds more than that of water. (Al-Trabulsy et al. 2013) These includes: antimony, arsenic, bismuth, cadmium, cerium, chromium, cobalt, copper, gallium, gold, iron, lead, manganese, mercury, nickel, platinum, silver, tellurium, thallium, tin, uranium, vanadium and zinc. Essential metals when present in higher concentration show toxic effects as well. (US FDA) Food and Drug Administration in 2011.

Exposure to metals may occur through the diet, medications, environmental exposure and cosmetics use. (Adal and Tarabar, 2013) The use of underarm anti-perspirant has been investigated as a possible cause of breast cancer. Basis for breast carcinogenesis may be due to the binding of various chemical constituents including metals to DNA and promotion of damaged cells growth, that's why some directives banned the use or presence of the heavy metals, $\mathrm{Cd}, \mathrm{Co}, \mathrm{Cr}, \mathrm{Ni}$, and $\mathrm{Pb}$ as impurities in the preparation of cosmetics. (Darbre, 2003 and, Bocca et al. 2007) Information about dermal exposure to metal toxins is very scanty, and few data exist on the personal care products and their role in inducing toxicities. (Ayenimo et al. 2010).

The study of metal content in some cosmetic products raise the concern about potential public health hazards; though, metals in cosmetic products are not currently regulated by the FDA. Although metal concentrations in cosmetic products have been reported by studies performed in many countries (Adepoju-Bello et al. 2012; Al-Saleh and Al-Enazi 2011; Al-Saleh et al. 2009; Brandao et al. 2012) interpreting how these reported concentrations may be related to potential health risk is challenging. The increasing health awareness and, the increased availability of cosmetic products in different markets draws the attention of researchers and clinicians to find adverse effects related to heavy metal contamination. (Saeed et al. 2010 and, Barakat 2011) Although some cosmetics are benign; others can cause or are supposed to cause harmful effects such as cancer, allergic reaction, mutations, as well as respiratory, developmental and reproductive problems. CDC (2003) High levels of cadmium has been linked to DNA mismatches. Increased zinc levels has been reported to produce clinical illness similar to that caused by lead toxicity, and can easily be mistakenly diagnosed as lead poisoning. (Theresa et al. 2011).

There are currently no international standards for impurities in cosmetics. Limits have been established in Germany. Rather than taking a risk-based approach, the German limits are based on levels that could be technically avoided. Thus, heavy metal impurities were limited to anything above normal background levels. Heavy metal levels in cosmetic products above the values listed later are considered technically avoidable. Lead: 20 ppm, Arsenic: 5 ppm, Cadmium: 5 ppm, Mercury: 1 ppm, Antimony: 10 ppm. (Al Dayel et al. 2011).

Health Canada has taken a similar approach in the establishment of heavy metal impurity limits, as the department has always maintained that impurities in cosmetics should be reduced to the extent that is technically feasible. Health Canada (2011) Most of the cosmetic samples in this study were found to contain high concentration of metals, particularly; $\mathrm{Pb}, \mathrm{Al}, \mathrm{Cu}, \mathrm{Ni}, \mathrm{Mg}$ and $\mathrm{Zn}$ which showed a wide variation among the samples and products. 
The differences in concentration of the studied metals between the samples may be attributed to the difference in the origin of the cosmetic samples.

Aluminium was detected in nearly most of the studied samples (22 samples), whereas $\mathrm{Pb}, \mathrm{As}, \mathrm{Cd}, \mathrm{Cr}, \mathrm{Cu}$ and $\mathrm{Ag}$ were detected in all the studied samples. Significant concentrations of aluminium $(5505 \pm 31.64 \mathrm{ppm})$ have been found in one product (sample 15) and $5311 \pm 66.58 \mathrm{ppm}$ in sample number (10). Worth mentioning, Al-Saleh et al. (2011) had highlighted the adverse developmental effects of aluminium toxic exposure on children and infants.

Cobalt, Barium and Nickel were the least detected elements. Cadmium, chromium and Silver were detected in all samples, while Cobalt was only detected in ten samples. Some directives banned the use of heavy metals, $\mathrm{Cd}, \mathrm{Co}, \mathrm{Cr}, \mathrm{Ni}$, and $\mathrm{Pb}$ as impurities in the preparation of cosmetics. EC (2003), Bocca et al. (2007) Very high lead concentration was measured also in four samples which reached 96.43, 21.4, 17.4 and $14.85 \mathrm{ppm}$ in samples number $(8,9,25$, and 24) respectively. This high lead value poses an alert for all users of such products, as any cosmetic product is considered technically avoidable when they exceed the $10 \mathrm{ppm} \mathrm{Pb}$ limits (Health Canada, 2011). It is likely that an exposure to more than $0.005 \mathrm{ppm}$ of cadmium can be hazardous to human health However, level of exposure that is well thought-out as a high limit is diverse because the cadmium effect may increase or decrease depending on other factors as the form, type and duration of exposure (ATSDR 2012).

Arsenic was detected in all the studied samples, the highest level detected was 3.927 (sample 22), six of the studied samples showed results for As higher than $3 \mathrm{ppm}$ which is the permissible As level in cosmetics (Health Canada, 2011). Fifteen (15) of the tested samples contained nickel, with levels ranging from $1.53 \mathrm{ppm}$ in sample (15) to $23.1 \mathrm{ppm}$ in sample number (3). The presence of high concentrations of nickel (more than $5 \mathrm{ppm}$ ) was detected in eight samples of studied cosmetic products. Usually, nickel salts are used as dye mordant and pigments. Nickel allergy caused by eye shadow has been reported by Sainio et al (2000), who reported that even $1 \mathrm{ppm}$ may set off a pre-existing allergy.

Maximum concentration of Copper was $49.1 \mathrm{ppm}$ detected in sample (12) which is higher than many of the studies conducted for cosmetic products. Ayenimo et al (2010), Theresa et al. (2011). The maximum value of cobalt (3.34 ppm) obtained in this study in sample number (6) was found to be lower than those reported elsewhere. Amartey et al. (2011), Nnorm et al. (2011)

The metals analyzed in this study were not listed as ingredients on any of the tested products. Due to absence of manufacturer testing and regulatory monitoring of such products, it is possible that the producing companies are not even attentive that their commercial final products are contaminated. These metal contaminants likely get into the products when below standard ingredients are used. Manufacturers should test the used raw ingredients before using them in making the final products to be able to track the origin of such contaminants. Ayesha Al-Suwaidi et al. (2010)

Recently, awareness has been drawn to PPD use in many brands of black henna dyes and the possibility to cause hyper sensitivity reactions in many individuals. (Nawaf AM et al. 2003) Recently PPD has been mixed with natural henna to give an ebony dark black colour instead of the orange/reddish colour given by natural henna, and to hasten fixation time as well. (Neri I et al. 2002)

Acute short-term exposure to high levels of PPD may cause severe dermatitis, pruritic, oedematous, erythematous scaly patches and vesicular dermal lesions, in addition to eye irritation and tearing. (Oztas MO et al. 2001) Severe allergic reactions to PPD can result in asthma, gastritis, renal failure, vertigo, tremors, anaphylaxis, convulsions, and coma.. (Redlick F. 2007)

The highest concentration of PPD reported by this study (35.21\%) was significantly higher than that reported by Ayesha Al-Suwaidi et al. (2010) (29.5\%), Brancaccio et al. (2002) in their studies $(15.7 \%)$.

The concentration of PPD in the seven black henna samples was higher than the maximum concentration of PPD found in hair dyes when applied to hair as specified by Scientific Committee on Con- sumer Products (SCCP) which is $2.0 \%$. The concentration of PPD reported by this study was higher than the permitted concentration of PPD in hair dye products established by the European Union, which is $6.0 \%$. The European Union has banned the use of PPD directly on the skin, eyelashes or eyebrows, and FDA as well has prohibited the use of PPD directly on the skin. Brancaccio et al. (2002).

\section{Conclusions}

The current study revealed that the continuous use of such contaminated cosmetics could result in an increase in some metal levels in the human body beyond acceptable limits. Such findings call for an instant mandatory regular testing programs to check metals' concentration in cosmetic products that are imported to Egypt, Saudi Arabia and other parts of the Arabian markets in order to limit their plethora and hence protect the consumers' health. Further efforts are needed to enlighten the users and the general public on the dangers of using unknown misbranded products that are pumped in large quantities to many markets in the Arab world.

\section{References}

[1] Adal A, Tarabar A. (2013): Heavy Metal Toxicity, http://emedicine.medscape.com/article/814960-overview.

[2] Adepoju-Bello AA, Oguntibeju OO, Adebisi RA, Okpala N, Coker HAB. (2012): Evaluation of the concentration of toxic metals in cosmetic products in Nigeria. Afr J Biotechnol; 11:16360 - 4.

[3] Ahmed S, Rahman A, Alam A, Saleem M, Athar M, Sultana S (2000):Evaluation of the efficacy of Lawsonia alba in the alleviation of carbon tetrachloride-induced oxidative stress. J. Ethnopharmacol. 69: 157 - 64. http://dx.doi.org/10.1016/S03788741(99)00091-4.

[4] Al-Dayel O, Hefne J, Al-Ajyan T. (2011): Human exposure to heavy metals from cosmetics. Orient. J. Chem. 27 (1), 01-11.

[5] Al-Saleh I, Al-Enazi S, Shinwari N. (2009): Assessment of lead in cosmetic products. Regul Toxicol Pharmacol; 54:105-13 http://dx.doi.org/10.1016/j.yrtph.2009.02.005

[6] Al-Trabulsy, HAM, Khater AEM, Habani, FI. (2013): Heavy elements concentrations, physicochemical characteristics and natural radionuclides levels along the Saudi coastline of the Gulf of Aqaba. http://dx.doi.org/10.1016/j.arabjc.2010.10.001.

[7] Amparo Salvador and, Alberto Chisvert (2007): General Concepts and Cosmetic Legislation, In: Analysis of cosmetic products. Elsevier; Kidlington, Oxford; 1 - 42.

[8] Amartey, E.O., Asumadu-Sakvi, A.B., Adjei, C.A., et al. (2011): Determination of heavy metals concentration in hair pomades on the Ghanian market using atomic absorption spectrometry technique. Br. J. Pharmacol. Toxicol. 2 (4), 192-8.

[9] ATSDR: Agency for Toxic Substances and Disease Registry, (2012): Public Health Statement for Cadmium: September 2012. Available at http://www.atsdr.cdc.gov. Accessed on 10.04.2013.

[10] Ayenimo JG, Yusuf AM, Adekule AS, Makinde OW (2010): Heavy metal exposure from personal care product. Bull. Environ. Contam. Toxicol. 84, 8-14. http://dx.doi.org/10.1007/s00128-0099867-5.

[11] Barakat MA. (2011): New trends in removing heavy metals from industrial waste water. Arab. J. Chem. 4, 361-77. http://dx.doi.org/10.1016/j.arabjc.2010.07.019.

[12] Bocca B, Forte G, Petrucci F, Cristaudo. (2007): Levels of nickel and other potentially allergenic metals in Ni-tested commercial body creams. J. Pharm. Biomed. Anal. 44, 1197- 202. http://dx.doi.org/10.1016/j.jpba.2007.04.031.

[13] Bolann BJ, Rahil-Khazen R, Henriksen H, et al. (2007): Evaluation of methods for trace-element determination with emphasis on their usability in the clinical routine laboratory. Scand J Clin Lab Invest; 67: 353-366. http://dx.doi.org/10.1080/00365510601095281.

[14] Bolduc C., Shapiro J (2001): Hair care products: waving, straightening, conditioning, and coloring, Clinics in Dermatology, 19 (4), 431 - 6. http://dx.doi.org/10.1016/S0738-081X(01)00201-2.

[15] Brancaccio RR, Brown LH, Chang YC, Fogelman JP, Mafong EA, Cohen DE. (2002): Identification and Quantification of ParaPhenylenediamine in a Temporary Black Henna Tattoo. Am. J. 
$\begin{array}{lrr}\text { Contact } & \text { Dermot; } & 13: 15 \\ \text { http://dx.doi.org/10.1053/ajcd.2002.30466. }\end{array}$

16] Brandao JDO, Okonkwo OJ, Sehkula M, Raseleka RM. (2012): Concentrations of lead in cosmetics commonly used in South Africa. Toxicol Environ Chem; 94:70-7 http://dx.doi.org/10.1080/02772248.2011.633911.

[17] Brown, V.J., (2013): Metals in lip products a cause for concern? Environ. Health Perspect. 121, A196. http://dx.doi.org/10.1289/ehp.121-a196.

[18] CDC, Centres for Disease Control and Prevention (2003): Second National Report on Human Exposure to Environmental Chemicals. http://www.cdc.gov/exposurereport/2nd.

[19] Charles Z. (1986): The Science of hair care, Marcel Dekker Inc. Madison Avenue, New York, NY 10016, U.S.A. pp 409 - 14.

[20] Darbre PD. (2003): Underarm cosmetic and breast cancer. J. Appl. Toxicol. 23 (2), 89-95. http://dx.doi.org/10.1002/jat.899.

[21] EC (2003): Directive 2003/15/EC of the European Parliament and of the Council of 27 February 2003 amending Council Directive $76 / 768 / \mathrm{EEC}$ on the approximation of the laws of the Member States relating to cosmetic products Official Journal of the European Union, 11.3.2003, L 66: 26-35.

[22] Groot ACD, Nater JP, Weyland JW. (1994): Unwanted Effects of Cosmetics and Drugs Used in Dermatology, third ed. (issue 1). Elsevier, pp. 2-15.

[23] Hatem Abdel Moniem Ahmed, Ragaa Mohamed Abdel Maaboud and, Fathy Fahim Abdul Latif et al. (2013): Different Analytical Methods of Para-Phenylenediamine Based Hair Dye. Journal of Cosmetics, Dermatological Sciences and Applications; 3: 17-25. http://dx.doi.org/10.4236/jedsa.2013.33A1003.

[24] Health Canada, Consumer product safety, (2011): Draft guidance on heavy metal impurities in cosmetics. Available: http://www.hcsc.gc.ca/cpsspc/legislation/consultation/_cosmt./meta lmtauxconsulteng php.

[25] J. H. Draize, (1944): Methods for study of irritation and toxicity of substances applied topically to the skin and mucous membranes. J. Pharmacol. Experim. Therapeutics 82: 377- 90.

[26] Kumar S, Singh VV, Singh M. (2005): Agro-History, Uses, Ecology and Distribution of Henna (Lawsonia inermis L. syn. Alba Lam), Henna Cultivation, Improvement and Trade, 11- 12; Jodhpur, India.

[27] Lahsissene H, Kahouadji A. (2010): Ethno botanical study of medicinal and aromatic plants in the Zaer region of Morocco. Phytother. 8: 202 - 9. http://dx.doi.org/10.1007/s10298-010-0569-2.

[28] Marcelo E. Conti, Francesco Botre, Franco Mazzei (1996): On the heavy metals content in cosmetic formulations: an atomic absorption spectroscopy investigation, J. Appl. Cosmetol. 14: 147-54.

[29] Nawaf AM, Joshi A, Nour-Eldin O. (2003): Acute allergic contact dermatitis due to Para-phenylenediamine after temporary henna painting. J Dermatol; 30:797-800. http://dx.doi.org/10.1111/j.13468138.2003.tb00480.x.

[30] Neri I, Guareschi E, Savoia F, Patrizi A. (2002): Childhood Allergic Contact Dermatitis from Henna Tattoo. Pediat Dermatol; 19:503-5. http://dx.doi.org/10.1046/j.1525-1470.2002.00219.x.

[31] Omolaoye JA, Uzairu A, Gimba CE. (2010): Heavy metal assessment of some eye shadow products imported into Nigeria from China. Arch Appl Sci Res; 2 (5): 76-84.

[32] Oztas MO, Onder M, Oztas P, Atahan C. (2001): Contact allergy to henna. J Eur Acad Dermatol Venereol; 15:91-2. http://dx.doi.org/10.1046/j.1468-3083.2001.00205-13.x.

[33] Redlick F, Dekoven J. (2007): Allergic contact dermatitis to paraphenylene diamine in hair dye after sensitization from black henna tattoos: a report of 6 cases. Can Med Assn J; 176:445-6. http://dx.doi.org/10.1503/cmaj.061109.

[34] Roy P K, Singh M, Tewari P. (2005): "Composition of Henna Powder, Quality Parameters and Changing Trends in its Usage". Henna: Cultivation, Improvement, and Trade. Jodhpur: Central Arid Zone Research Institute; pp. 39-40.

[35] Saeed M, Muhammad N, Khan H, Khan SA. (2010): Analysis of toxic heavy metals in branded Pakistani herbal products. J. Chem. Soc. Pak. 32, 471-5.

[36] Sainio E. L., Jolanki R., Hakala E., Kanerva L. (2000): Metals and arsenic in eye shadows. Contact Dermatitis 42:5-10. http://dx.doi.org/10.1034/j.1600-0536.2000.042001005.x.

[37] Scientific Committee on Consumer Products (SCCP, 2006): Opinion on P-phenylenediamine. In (Public Health and Risk Assessment) 9th plenary meeting, Brussels, Belgium.

[38] Theresa OC, Onebunne OC, Dorcas WA, Ajani OI. (2011): Potentially toxic metals exposure from body creams sold in Lagos, Nigeria. Researcher 3 (1), 30-7.
[39] US FDA, United State Food Drug and Cosmetic Act on Hazardous Chemicals in Cosmetics (2011): Available: http://www.fda.gov/opacom/ laws/fdcact/fdctoc.htm.

[40] Yagi H, El Hind AM, Khalil SI. (1994): Acute poisoning from hair dye. East Afr Med J 68: 404-11. 